\title{
Revisiting the Charge of Tahrīf: The Question of Supersessionism in Early Islam and the Qur'an
}

\author{
Sandra Toenies Keating
}

In recent times, a great deal of interest in bringing about peace and harmonious relations between Muslims and Christians has been generated, both within the walls of the academy and beyond. This renewed interest has caused many aspects of the interactions between the two communities to be reassessed, resulting in an explosion of new research, editions, and translations of significant texts, and fresh insights into ancient questions. On the whole, this movement has been positive and productive, engaging people from around the globe in an endeavor that could have far-reaching consequences.

There has also been the propensity, however, to downplay real points of disagreement in an effort to reach the goal of peace. Nowhere is this more apparent than in the tendency to discount the importance of the theological convictions of the communities being studied. In many cases, researchers with little interest in or sensitivity to theological questions discount such evidence as 'bias' in an effort to find 'what really happened.' For some, the answer to tensions between adherents of the two religions is simply to conclude that debates about 'abstract and theoretical' questions of truth are useless in the academy, since no definitive conclusions can be reached by human inquiry. Unfortunately, in many cases this has led to historical and linguistic studies that, although helpful, neglect the cultural values and overall intentions of the author(s) of the texts or of the community within which these texts were preserved and transmitted. Thus, conclusions are drawn concerning texts and accounts of events without taking seriously the theological impact they have had on the communities that preserved them. This approach, moreover, imposes contemporary (often academic) interests and assumptions on authors and communities far removed from our own concerns. One can identify such non-theological interpretations in almost every area of Islamic studies, which has generally been relegated to history, political science, or religious studies.

Nevertheless, these non-theological interpretations obscure the religious convictions of the founder of Islam and his followers. It seems that almost from the very beginning, Muhammad understood himself as a religious reformer, drawing his listeners back to the primordial worship of the One God. It is very clear from the earliest sources that Muhammad and his followers believed that he was a prophet like the prophets of the Jews and Christians, 
and he expected that his message would be recognized and accepted by those communities. When they did not welcome him as one of their own, however, an explanation was necessary. It is here that the notion of tahrif comes into play. In its developed form, tahrif is the Islamic teaching that the scriptures of other monotheists and/or their interpretations have been corrupted, and thus obscure the message that had been previously sent by God. The implication of tahriff is that the Qur'ān comes both to confirm (cf. Sura 4:46-7) and to correct errors in the teachings of the Jews and Christians, making Islam not simply another monotheistic religion, but rather, the final and most pure revelation by which all others are measured. In recent years, however, some scholars have argued that this was not Muhammad's intent, and that supersessionist ideas should be attributed instead to later sources.

A particular movement among researchers into the origins of the Qurān and the early Islamic community has thus postulated a rather late appearance of sectarian Islam. This movement has taken off in two general directions. One group, characterized by the provocative book of Christoph Luxenberg, ${ }^{1}$ has sought to demonstrate that the religion now known as Islam has its origins in an initial confusion over earlier Syro-Aramaic texts, perhaps as the result of a misguided attempt to evangelize the Arabs. A related view is that the body of literature traditionally identified as the Qurân came to be associated with the Arab chieftain Muhammad at a later date, even though he was only peripherally responsible for it. These scholars have also tended to emphasize socioeconomic rather than theological reasons for the rise of Islam. ${ }^{2}$

A second group of scholars has taken a more irenic approach, suggesting that the earliest followers of Muhammad were an inter-confessional group including Jews, Christians, and other monotheists who, according to Fred Donner, ${ }^{3}$ called themselves 'Believers' and whose primary criterion for membership was belief in the one God. They argue that it was only later, perhaps more than a century after Muhammad's death, that the sayings and traditions associated with him were collected together into the present forms of the

1 Christoph Luxenberg, The Syro-Aramaic Reading of the Koran: A contribution to the decoding of the language of the Koran (Berlin: Verlag Hans Schiler, 2007).

2 In this group I would include many of the contributions of Patricia Crone and Michael Cook and their followers. Theories about the relationships among the appearance of early Islam, Muhammad, and the Qurān are in flux and beyond the scope of this paper. For a good summary of several of them, see Stephen J. Shoemaker, The Death of a Prophet: The End of Muhammad's Life and the Beginnings of Islam (Philadelphia, Pennsylvania: University of Pennsylvania Press, 2012), especially the Introduction and chapters 1-2.

3 Fred M. Donner, Muhammad and the Believers: At the origins of Islam (Cambridge, Massachusetts: The Belknap Press of Harvard University Press, 2010), see especially chapter 1. 
Qurān, Sīra (biography), and hadìth. Consequently, these texts reflect not the original teachings of Muhammad, but rather, a later ideology desiring to establish the community of Believers separate from Christians and Jews. Thus, the ideology shifted from an early emphasis on the commonality of Jewish, Christian, and general monotheistic belief in the One God, the impending Hour of Judgment, and the importance of Syro-Palestine, to the creation of a separate identity for 'Those Who Submit' (muslimūn) and the sacred geography of Arabia. ${ }^{4}$

Recently, a proponent of this approach, Stephen J. Shoemaker, has published an intriguing book entitled The Death of a Prophet, ${ }^{5}$ which builds upon the work of previous scholars such as Donner, Cook, Crone, and Wansbrough. He proposes that the most significant characteristic of the earliest community of Believers who had gathered around Muhammad was the shared belief in an imminent eschatology - the expectation that the final Hour would arrive within the lifetime of Muhammad. Remnants of this teaching can be found both in non-Muslim accounts of the appearance of Islam, as well as in the reshaped orthodox accounts of Muhammad's death. Shoemaker argues, rather convincingly I believe, that when Muhammad died before the coming of the final Hour, his followers needed to rethink and reinterpret his message, ultimately leaving the eschatological aspects of his teaching aside. As a consequence, the contents of the Qurān and Sīra were systematized at a date quite removed from Muhammad's life. They reflect an attempt to collect the material and put it into an order that would make sense out of both the truth of Muhammad's message (and its confirmation through the success of the Islamic conquests) and how events had actually turned out — the Hour had not arrived as expected. I find many aspects of Shoemaker's arguments thought-provoking, and his collection and analysis of early non-Muslim accounts of the rise of Islam is quite helpful. However, he is not able to effectively account for the gap between his hypothetical version of the early community and demonstrable characteristics of Islam less than a century later. ${ }^{6}$

As compelling as the vision of an irenic prophet and his multi-cultural followers is, I am inclined to question many of the conclusions reached by these

4 See various contributions of Patricia Crone and Michael A. Cook, Hagarism: The Making of the Islamic World (Cambridge: Cambridge University Press, 1977); Patricia Crone, Slaves on Horses: The Evolution of the Islamic Polity (Cambridge: Cambridge University Press, 1980); Suliman Bashear, Arabs and Others in Early Islam, vol. SLAEI 8 (Princeton: Darwin Press, 1997); and John E. Wansbrough, The Sectarian Milieu: Content and Composition of Islamic Salvation History, vol. London Oriental Series 34 (Oxford: Oxford University Press, 1978).

5 Shoemaker, Death of a Prophet.

6 See my review of Shoemaker's book in Hugoye 16/1 (2013): 160-165. 
recent books. Two issues in particular do not seem to be accounted for in this approach to the origins of Islam. First, while he is to be commended for taking seriously the evidence found in non-Muslim sources for evaluating the Muslim tradition, Shoemaker has paid little attention to a significant source, namely, those texts that recount early interactions between Muslims and Christians that reveal a deeper awareness of theological differences between the two communities. For example, Christian writers in Greek, such as Anastasius of Sinai (d. ca. 700), ${ }^{7}$ and in Syriac, such as Jacob of Edessa (d. 708), ${ }^{8}$ are quite aware of the teachings of Muslims that are critical of Christian beliefs concerning the Trinity and Incarnation. These, along with several other references to the beliefs and practices of the young Muslim community, imply that at least the broad outlines of Islam's distinctive characteristics were already in place by the end of the seventh century. This is a little-studied area of inquiry, primarily because until recently it was assumed that non-Muslim sources were of little value for understanding what was taken to be a firmly established account of Muslim origins.

Second, although the Qurān was collected and preserved in a manner that appears random, it nonetheless reflects a more developed theological system than these theories acknowledge. One finds in the Qurān a distinctive understanding of revelation, sin, covenant, prophethood, ethics, etc. A peculiar aspect of the Qur'ann, though, is that it does not reflect any attempt to organize the material thematically or historically. In fact, it seems difficult to explain why, if the text was collected and edited in the eighth or even early ninth century as a few scholars have proposed, more effort had not been given to making it more consistent and orderly, as one finds in the Sīra and hadith. ${ }^{9}$ Furthermore,

7 For example, he complains that the Arabs accuse Christians of worshipping two gods (cf. Qurān 16:51, as well as 5:116, in which Jesus denies that he taught his followers to worship himself and his mother as gods). Viae dux I.1, 9 (PG 89, 41A), cited in Robert G. Hoyland, Seeing Islam as Others Saw It: A survey and evaluation of Christian, Jewish and Zoroastrian writings on early Islam, Studies in Late Antiquity and Early Islam 13 (Princeton, New Jersey: The Darwin Press, Inc., 1997), 107.

8 Sidney H. Griffith, The Church in the Shadow of the Mosque: Christians and Muslims in the World of Islam (Princeton: Princeton University Press, 2008), 30-33.

9 Shoemaker sees the possibility of parallels in the formation of the New Testament canon and that of the Qurān. One great difference, though, is that the New Testament writers were apparently interested in offering their readers a consistent 'story line' within a particular context (e.g., Matthew is concerned with demonstrating the ways in which Jesus fulfilled Jewish prophecy, Luke is writing for Gentile converts). The Qurān, however, does not exhibit any attempt at order or even desire to give a clear answer to particular questions. If the collectors and redactors had a particular agenda, they were certainly not as effective in communicating it as they might have been! 
if the Qur'ān had been written down as late as some are suggesting, the clear misunderstanding of Christians and Christianity found in it becomes even more puzzling. How could the Qur'an have been so mistaken about the role of Jesus, Mary, and the Trinity in Christian doctrine during a period in which there was close contact between Muslims and Christians? ${ }^{10}$ If one assumes a very early date for the verses concerning Christian teaching, these errors could be explained as the result of misinformation; later dating, however, renders them inexplicable. ${ }^{11}$

Therefore, the question ultimately is: how aware was the initial community of Muhammad's followers (indeed, Muhammad himself) of the differences between his message and what was regarded as 'orthodox' Christianity and Judaism in the Arabian Peninsula? It has long been recognized that the canonical Qur'ān contains apparently contradictory verses, which can best be understood when assigned to particular contexts. Although the extent to which it is possible to associate these verses with a specific period in Muhammad's life (e.g., 'Meccan' or 'Medinan') has recently been called into question, it nonetheless remains clear that the early community felt compelled to include all of these verses, meaning that it attributed some sort of authority to them. The verses can be grouped together according to the extent that they reflect a positive/optimistic or a negative/skeptical view of the teachings and behavior of Christians and Jews. Given the fact that those verses that display a negative view also imply the possibility of having some authority and power over these other communities, one can surmise that they belong to a later period, after Muhammad's ascendancy had begun. Furthermore, these verses appear to exhibit a development, as Muhammad and his followers began to reflect on what they believed God was doing at that point in history. Inconsistencies and even apparently outright contradictions are likely explained as reflecting historical development in Muhammad's thought and experience. The accounts of Christians, Jews, and both their scriptures found in the Qurān reflect such a development, and the earliest evidence of the teaching of tahrîf can give us some insight into the issue.

10 Jane Dammen McAuliffe, Qur'ānic Christians:An Analysis of Classical and Modern Exegesis (Cambridge: Cambridge University Press, 1991).

11 An explanation of the odd references to Christian teachings that include Mary in the Trinity (4:171, 5:116) and the seemingly garbled account of the Last Supper (5:112-7) has eluded scholars and commentators. Over the centuries some have suggested that these refer to aberrant Christian groups or to Muhammad's confusion about these doctrines. A major contribution toward answering this problem has been made by Sidney H. Griffith in his recent book, The Bible in Arabic: the Scriptures of the 'People of the Book' in the Language of Islam (Princeton: Princeton University Press, 2013). 
As I will argue below, the formulation of the doctrine of tahrif gives us a strong indication that Islam was from its inception supersessionist - the view that the new revelations sent by God would replace the corrupted scriptures possessed by other communities. Muhammad seems to have gradually come to understand himself as a reformer, first bringing the Arabian polytheists to monotheism, and then drawing Jews, Christians, and other monotheists back to their original scriptures. Thus, although, he did not assume that God had commanded identical customs or languages for all people, it seemed clear to him that God would not command contradictory things of different people. Muhammad's teachings thus reflect a unification of monotheistic groups, but with a particular vision of what society should look like. In this sense, the Qurān could be seen as a 'corrective,' as well as a confirmation of what had come before.

\section{Revelation and Supersessionism}

One of the intriguing questions surrounding the origins of the Qur'an is the context that prompted its appearance. Was it a reaction against closed Christian and Jewish communities who made no attempt to draw Arabian polytheists toward monotheism? Or was it the desire of Muhammad and his followers to have a religion in the monotheistic tradition that expressed particularly Arabian norms and values, which was then transformed into a religion claiming roots in the family of Abraham? In my opinion, a glaring problem with current theories of the origins of Islam is the lack of a compelling account of why the early followers of Muhammad did not simply join any of the monotheistic communities available in the Arabian Peninsula at the time, of which there was apparently a wide variety. There are many reasons to expect that the inclination of the tribes toward monotheism would bring them within the folds of Judaism, Christianity, or Zoroastrianism, as had already happened in northern Arabia. Certainly by the end of the sixth century there seems to have been a self-conscious movement among historically polytheistic Arabians toward monotheistic beliefs and nominally Jewish practices. The Qurān, however, does give us a few hints at the answer to this question, suggesting that the revelation to Muhammad is an 'Arabic reading' (qur'änan 'arabiyyan) of 'the clear Book' (al-kitābi-l-mubīn), which brings what had previously been revealed in other languages to the Arabic-speaking tribes (Sura 12:1-3). One might identify in this clue some parallels to the early mission to the Gentiles among the followers of Jesus - the belief that it was imperative that God make the revelation known to these peoples in their native tongue. 
Our available sources do not provide a coherent report of the earliest stages of the interplay between the messages Muhammad received and his interpretation of their meaning and implications. Nonetheless, even if one rejects the traditional Islamic account of the origins of the Qurān and Islam, it does seem to be the case that Muhammad and his followers saw themselves as submitting to an ancient set of monotheistic beliefs and rituals that was different from those of their polytheistic ancestors; the evidence also suggests that the change was prompted by private revelations that had come to Muhammad. These monotheistic beliefs included submission to a single, all-powerful and all-knowing, merciful Creator God, a particular moral perspective that demanded a certain relationship with that God, and apparently an imminent eschatology that expected cosmic judgment. All of these have strong counterparts in nearly every form of Judaism and Christianity. Thus, there is no reason to believe that the original community of 'believers' did not see themselves as participating in a larger monotheistic community, accepting what had been revealed as Truth many times before, while at the same time being concerned that what they held was not exactly what their Jewish and Christian neighbors professed.

A growing awareness of discrepancies between Muslim beliefs and those of other monotheists is evident in the Qurān, although not in a systematic way. Rather, in numerous Suras, statements are made in defense of the primacy of the Qur'ann whenever Christians and Jews make claims that contradict a revelation to Muhammad. These references imply that quite soon after the appearance of Muhammad, differences between the messages he delivered and the teachings of the Jews and Christians became apparent. Many theories have been advanced to explain the various references in the Qurann to this problem, ranging from denial that the Qurān rejects orthodox Jewish and Christian teaching, to the claim that Muhammad's intention was to eliminate all other religious practice. It may well be the case that early on Muhammad was quite convinced of the continuity between his message and that of Jews and Christians, but their refusal to recognize him on theological grounds eventually led to a breach. Thus, (and I believe this is the most likely scenario) he began to emphasize errors, first in their interpretation of their scriptures, and then even in the editions of the scriptures themselves.

The critiques of Jewish and Christian scriptures and their interpretations in the Qur'ān are bolstered by an insistence that Muhammad is a prophet in a long line of prophets who brought the same message to their followers. Seen as a whole, however, the Qur'ann presents a theology of revelation that is profoundly different from that of mainstream Judaism and Christianity, in that a fixed text is identified as the fundamental means of divine communication. Whereas God is understood as revealed in the divine relationships of the 
Covenant (seen in God's actions and commands) for the Jews and in the Incarnation for Christians, the Qurān emphasizes instead the clarity and constancy of God's commands. Theologically, one can say that the Jewish and Christian view of 'salvation history' (a Christian term) is that God's plan for His relationship with humanity unfolds over time, a process that is both ongoing and mysterious. The Qur'ān, on the other hand, is insistent on God's unchanging relationship with Creation, a relationship that was made known even in the first revelation to Adam (Sura 2:30-5).

Nevertheless, there are some difficulties with the Biblical view of salvation history, two of which are relevant here. The first is that it is difficult to determine when a new event or 'revelation' should be interpreted as an authentic expression of God's will in His plan. The second is that it is difficult to explain how God can hold individuals equally accountable at the Divine Judgment. If some people were given different commands or did not know critical requirements, how can God justly judge them? For example, Abraham, whom all Jews, Christians, and Muslims revere, had neither the Mosaic Law nor the sacraments, both of which are understood to be obligations by their respective communities. Over the centuries, Jews and Christians have sought to account for this problem in various ways that cannot delay us here. What this problem does throw into relief, though, is the primary purpose of the Qurān: to explain how the new Arabian monotheists fit into God's ancient plan of salvation. The Qur'ān proposes that Divine justice requires that God's will for human beings be knowable, known, unchanging, and within human capabilities. Thus, there must be a single clear revelation that has been accessible to all human beings in order for God to judge justly. Because God has been revealed as Merciful and Just, He has indeed made His will known to all people so they cannot say on the Last Day that they did not know. ${ }^{12}$ The Qurān is the most recent (and final) copy of that revelation sent to humanity.

According to the Qur'ān itself, God sent down the revelation to Muhammad as a 'mercy' (rahm) and a 'reminder' (dhikr) to those who would believe. Muhammad was commanded by the Angel Jibril (Gabriel) to recite what he would be given. The recitation (qur'ān) would come from the divine source, the Preserved Tablet (Sura 85:22). This Preserved Tablet (Lawh al-Mahfüz) is also referred to as the Umm al-Kitāb, the Mother of the Book (3:7), which is preserved and guarded from all corruption (15:9). It is a fixed text, unchanging and reliable, which guarantees God's promise of mercy and justice. Among the many verses illustrating this is Sura 43:2-4: "[By] the Clear Book, We have made it an Arabic recitation [Qurān] so that you may understand, and it is in the 12 Among the many examples, Sura 7 gives an extended account of the final Judgment,
emphasizing that no one will be able to hide from God's justice. 
Mother of the Book in our Presence, high, wise."13 Significantly, the Qur'ān is characterized here as being 'in' $(f \grave{\imath})$ the Umm al-Kitāb, but the verse does not imply that it is the totality of the Umm al-Kitäb. The Qur'ān is, rather, the final revelation sent down to humanity as a guide on the 'straight path,' as well as the confirmation and 'correction' of all previous authentic revelations. The very use of the word qur'ann to describe the revelation implies that it is the reading of a preexistent text, a text that has been revealed to others and that might be mysteriously read in a multitude of languages.

In line with this notion of revelation, the Qurann acknowledges that the 'Book' has been sent down previously to other chosen prophets, among them Adam, Abraham, Moses, and Jesus. To each of these God has sent a pristine copy of a part of the Umm al-Kitāb, so that every people is guided toward perfect submission to Himself (e.g., Sura 6:84-90;10:47; 16:36-7). God does this out of mercy and justice so that each person can be fully prepared for the Final Hour of Judgment. Significantly, these prophets are upright and trustworthy, unlike many of their followers. The Qurān includes numerous accounts of the prophets themselves reprimanding their followers for misunderstanding or refusing to accept the revelation they have been given. For example, in Sura 2:67-71 (The Heifer), the Israelites badger Moses into requesting of God more and more specifics concerning the red heifer they are to sacrifice, each time implying they cannot comply because they do not understand the command. In Sura 5:116-8, Jesus is described as defending himself on the Day of Judgment against those who worship him and his mother as gods. Thus, the blame for discrepancies in the teachings of the Jews and Christians is laid at the feet of the followers of the prophets, and not the prophets themselves, the revelation, or God.

Seen through this lens, many confusing and apparently contradictory passages in the Qurān make more sense. For example, oft-quoted passages such as "To each of you we have given a law and a clear path; and had Allah willed, $\mathrm{He}$ would have made you one people, but [He wants] to test you concerning what He gave to you" (Sura 5:48) and "to you your religion and to me my religion" (Sura 109:6 $)^{14}$ do not reflect the sort of progressive, pluralistic vision of society as contemporary thinkers wish to imagine. Rather, they are reminders that

13 All translations of the Qur'ān are my own, unless otherwise noted.

14 This verse is widely misunderstood by non-Muslims because it is usually quoted out of context. When read with the verses immediately preceding it, our point becomes clear: "Say: O you who are unbelievers ( $k a \bar{f} f i r u n n$ ), I do not worship what you worship and you do not worship what I worship. And I will not worship what you have worshiped, and you will not worship what I worship. To you your religion and to me my religion." 
there is no use disputing with those who do not recognize the authentic revelation - at the Final Judgment, God will vindicate His true servants. On this point, the arguments of Shoemaker are helpful. It seems very likely that the early 'Believers' did not waste time disputing with their fellow monotheists because they expected that the end was near and they would be justified soon. In the meantime, they needed to hold fast to the message God had now sent to them..$^{15}$

Muhammad and his followers were convinced that he was receiving a new iteration of revelations previously given, yet paradoxical verses in the collection of these revelations seem to point to a lack of knowledge about the actual beliefs of those to whom God had sent His angels before. It is only over time that Muhammad began to recognize exactly what was different, and what the implications of those differences were. Simultaneously, to understand why Muhammad and his 'Believers' did not simply become Jews or Christians, one has to assume that he thought he was receiving something new or distinctive, something that needed to be preserved in spite of its differences from the 'Books' of the Jews and Christians - something that should replace what they now possessed. It is in this sense that Islam was from its very origins supersessionist.

\section{Taḥîf and Supersessionism}

All of this leads to some significant questions about the theological perspective of early Islam. In this short paper, we will address two interrelated issues, which have a sort of 'chicken and egg' relationship. Perhaps the problem can be best expressed in the following questions: in what way did Muhammad and his followers understand the differences between what he was preaching and the teachings of other monotheists, and how did this come to be expressed in the Qur'ān? From an Islamic viewpoint, the true revelation was given first to Muhammad, followed by communal reflection on its differences from Jewish and Christian teachings. Historical-critical methods, however, have indicated that the multitude of verses commenting on the scripture, teachings, and status of Jews and Christians are likely the result of increased interaction with members of these communities. In any case, the early Muslim community felt it necessary to account for these discrepancies, and traditionally, Muslim answers to these questions have been found in the doctrine of tahriff. At this point we will give some general outlines of the sources for this teaching in the

15 See especially Shoemaker, Death of a Prophet, ch. 3. 
Qurān, and try to ascertain whether those who have questioned its importance for Muhammad and his early followers are correct.

The term tahriff comes from the second form of the Arabic root harafa, which means to slant or bend, distort, misconstrue, or falsify. The expression, as will be discussed below, refers both to a particular type of distortion of the revelation, as well as to distortion of revelation and its general interpretation. A broad definition of tahriff is the Islamic notion that Jewish and Christian scriptural texts, as well as subsequent interpretations of them, have been manipulated or misunderstood. Consequently, the Qur'ān itself claims that God sent this revelation down through Muhammad as a reminder of the true revelation. A particularly relevant passage concerning the relationship between previous scriptures and the Qurān states:

And We have revealed to you (Muhammad) the Book in truth, confirming what was already possessed of the Book and guarding ${ }^{16}$ over it. So judge between them according to what Allah has revealed, and do not follow their vain desires, diverging from what came to you of the Truth. To each of you we have given a law and a clear path; and had Allah willed, He would have made you one people, but [He wants] to test you concerning what He gave to you. Strive, then, towards good deeds. To Allah is the final goal of all of you, He will instruct you concerning that on which you differed. And judge between them with what Allah has revealed, and do not follow their vain desires. Beware of them lest they lure you away from part of what God has revealed to you. And if they turn away, know that Allah only wishes to punish them for some of their transgressions, and that many people are indeed rebellious! (Sura 5:48-49)

Passages such as these have traditionally been understood to teach that the Qurān is both a confirmation that God has revealed scripture to human beings (so they can be judged justly for their actions), and that the 'clear path' has been obscured by 'grave sinners,' necessitating a further corrective revelation. The Qurān thus affirms the authenticity of these previous scriptures while also correcting diverging accretions associated with them, among which are Christian teachings on the Trinity, Incarnation, and celibacy, as well as the suppression of revelations predicting the prophethood of Muhammad. As noted above, the understanding of revelation presented in the Qurann rejects any notion that God's will unfolds or that recent revelation 'builds on' what is more ancient, because such a belief calls God's justice into question.

16 Muhayminan: to 'amen' something; to guard, protect, or be master over something. 
In short, there is no principle of 'development of doctrine' as one finds in Christianity. Rather, tahrîf explains how the same revelation received by a myriad of prophets can exhibit such differences in the hands of the followers of those prophets. From the Qurānic perspective, the revelation to Muhammad remains the norm by which other revelations are judged for their authenticity, superseding and correcting all contradictions and deviations from it.

A complication for understanding the role of tahriff in early Islam is that the Qurān hints at the tension among the monotheistic communities in a multitude of ways, preventing any single clear-cut definition. Only a few studies have been made on the term in the Qurān, most significantly in an important (but not often cited) article by Caspar and Gaudeul. ${ }^{17}$ They note that several specific terms are used in the Qur'ān in relation to the divergence between what was taught by Jews and Christians and what Muhammad had 'received.' Each of these terms appears to refer to a different type of 'alteration' of the original revelation, ranging from simple misinterpretation or forgetfulness to intentional changing of meanings and even rewriting of the text. The terms can be categorized according to two recognizable groups: tahrîf al-ma'āni (alteration/corruption of the meaning of authentic scriptures) and tahriff al-naș (alteration/corruption of the actual text of the scriptures). A further distinction made within tahrîf al-ma'ānī is that of ta'wīl, or interpretation of the meaning. ${ }^{18}$ One finds these categories reflected in later commentators, who generally emphasize either the proclivities of Jews and Christians to misinterpret (intentionally or unintentionally) their scriptures, or who maintain that the extant Jewish and Christian scriptures have been physically altered. ${ }^{19}$

17 Jean-Marie Gaudeul and Robert Caspar, "Textes de la tradition musulmane concernant le tahrīf (falsification) des écritures," Islamocrhistiana 6 (1980): 61-104.

18 Gaudeul and Caspar, "Textes de la tradition musulmane," 61.

19 Several significant studies have been done on the later use of tahrif by Muslims, for example I. di Matteo, "Il 'tahrîif' od alterazione della Bibbia secondo i musulmani," Bessarione 38 (1922): 64-111, 223-60; Gaudeul and Caspar, "Textes de la tradition musulmane"; Hava Lazarus-Yafeh, Intertwined Worlds: Medieval Islam and Bible Criticism (Princeton: Princeton University Press, 1992); I. Resnick, "The Falsification of Scripture and medieval Christan and Jewish Polemics," Medieval Encounters (1996): 344-80; Hava Lazarus-Yafeh, "Tahrîf," in Encyclopedia of Islam, Vol. 10 (2000), 111a; and Martin Accad, "Corruption and/or Misinterpretation of the Bible: The Story of the Islamic Usage of Tahrif," Theological Review-Beirut (2003): 67-96; as well as the recent comments by Gabriel Said Reynolds, "On the Qur’anic Accusation of Scriptural Falsification (tahrīf) and Christian Anti-Jewish Polemic," Journal of the American Oriental Society 130/2 (April-June, 2010): 189-202. 
Under the two main headings introduced above, six different verbs or their derivatives are employed in the Quraan when speaking of the corruption of the scriptures through human interference: tahrîf, tabdīl, kitmān, labs, layy, and nisya $\bar{a} .{ }^{20}$ Verses that point to the attempt to distort the meaning of the scriptures often use the word kitmān, which connotes 'hiding or concealing,' (Sura $2: 42,140,146,159,174 ; 3: 71,187)$, and is sometimes found in conjunction with labs, 'disguising' (2:42; 3:71). Sura 2:42, for example, exhorts the Jews of Medina: "And do not disguise (talbisü) the truth with falsehood, nor conceal (taktumū) the truth, for you know it." A third term, lawā, meaning 'to twist,' suggests that pronunciation of certain words during the recitation of the scriptures was corrupted so that the listener either did not understand it properly, or would misunderstand (Sura 3:78; 4:46). For example, Sura 3:78 says of the People of the Book:

And there is among them a group who twist (yalwūna) the Book with their tongues, so you would think it is from the Book, but it is not from the Book; and they say 'it is from Allah,' but it is not from Allah, and they tell a lie against Allah and they know it.

In Sura 4:46, furthermore, this 'twisting' is used to explain tahrîf:

Some of the Jews alter the words (yuharrifunna) out of their places, and they say: 'We have heard and we disobey,' and 'Hear without Harkening,' and ' $r \bar{a} \bar{i} i \bar{a}, 21$ twisting (layyan) their tongues and slandering religion.

Here the verse suggests that by changing the words, the revelation is made to say the opposite of what God intended. The following verses continue with the explanation without clearly stating whether this twisting and alteration is intended, until it is clarified in verse 50 . In this verse, which brings the section to a conclusion, the underlying intentionality is finally discussed: "See how they invent the lie against Allah, and that alone is a clear sin!"

The Qurān also implies that false interpretation of the meaning of the scriptures stems from a disregard for important passages, or from simply forgetting certain revelations. The term nisyān, 'forgetting, overlooking,' is used both in reference to Jews (Sura 7:53, 165; $5: 13$ ) and Christians (5:14; 7:53). Sura 5:13-4 relates how God punished the Jews and Christians because they broke

20 Gaudeul and Caspar, "Textes de la tradition musulmane," 62-3.

21 This is a term of abuse. 
their Covenant by cursing them and making both of them "forget a large part of what was given to them."

A more serious form of tahrîf is tabdīl, the actual changing or substitution of the text of the scriptures with something not revealed. It is mentioned in the Qurān two times explicitly in connection with the Israelites living after Moses (Suras 2:59 and 7:162), in which it is clearly stated that evildoers among them 'substituted' (baddala) what was given to them by God with something else. According to the Qur'an, this intentional distortion of the scripture was not limited to the substitution of words in previously revealed texts; those who heard the new message also tried to corrupt it. In Sura 10:15, God instructs Muhammad to resist those who ask him to substitute (baddilhu) something else for the authentic revelations, either because they are too difficult or contradict the other scriptures. Instead, God tells him to say: "It is not for me to substitute it (ubaddiluha) [with something else] of my own accord..." Unlike the other forms of tahrîf found in the Qur'ān, tabdïl is unambiguously intentional: just as the unbelievers asked Muhammad to change the true revelations he was receiving, those who kept and interpreted previous scripture knowingly and deliberately altered what they had received. The seriousness of this accusation is obvious, and explains why later Christians and Jews felt the need to respond.

One should understand tahrïf, then, as an essential element of a comprehensive and coherent theory of revelation and divine justice. A shortcoming of some of the current scholarly work on this subject is the failure both to distinguish among the various types of corruption, and to understand the significance of each within this larger context. A common approach has been to emphasize the linguistic roots and the various meanings of the term, in order to support the particular theory of the origins of Islam that each researcher is seeking to defend. Consequently, the term tahrîf has been translated in different ways and often reflects the position of the scholar more than the intent of the text itself. These translations include 'falsification,' 'misinterpretation,' 'alteration,' or 'corruption,"22 all of which are sometimes correct, but can also lead to a misunderstanding of the purpose of the teaching. Too much emphasis on parsing terms can cause one to lose sight of the larger trajectory of the text and the intention of its author.

As we have seen above, the Qurānic understanding of revelation requires that an account be given of the obvious discrepancies (both minor and significant) between what Muhammad was receiving and the teachings and scriptures of the Jews and Christians. If God, out of mercy and justice, has revealed

This is a clear limitation of the arguments put forth by Reynolds and Accad. 
His divine will to prophets throughout human history, then all authentic versions of this revelation should be identical. But if the prophets have all received different messages, God cannot justly hold all people equally accountable. The teaching of tahrif offers an explanation of the existent discrepancies by placing the blame on human fallibility (and in some cases evil intentions), thus preserving God's integrity as just, merciful, and trustworthy. As a consequence, the Qurann is sent both to confirm what has been given before, and to remind people of the true revelation. All scripture and practice should therefore be judged and purified according to this Arabic revelation, which is presumably the final and perfect revelation so long as Muhammad's followers also take care that it is not corrupted.

Further support for the position that supersessionist teachings have their roots in the earliest period of Islam can be found in the writings of Christians living in the first two centuries after Muhammad. Along with those mentioned above who defended Christian doctrine and practice against Muslim efforts to convert them, one should add more well-known figures such as John, Patriarch of the Church of the East, John of Damascus, and the anonymous writer of the Treatise on the Trinity. The Damascene's systematic explanation of Christian faith, particularly his writings on the Trinity, is best understood within the wider context of the Umayyad conquest. His identification of Islam as a type of heresy is indicative of his opinion that the religion of the conquerors was a distinctive movement, one that saw itself as making truth claims that contradicted the teachings of orthodox Christianity and therefore required a lengthy rebuttal. ${ }^{23}$ Another example of someone who took up this problem is Abu Rāitịa al-Takrīitī, a Syrian Orthodox Christian who died around the year 830. He was one of the first to address the charge of tahrifif in a systematic way. Abu Rāitita took up the problem towards the end of his apology for the Trinity, where he presents a number of logical arguments against any suggestion that Christians and Jews have placed words into the mouths of the prophets, concealed what was revealed, or worse, substituted the words of revelation with other words. ${ }^{24}$ It is clear that all of these writers appear to have been engaged at a very early period in the defense of their beliefs and scriptures against attempts to replace them with the new revelation of the Qurān.

23 See, for example, Sandra Toenies Keating, "'Say Not Three': Some Early Christian Responses to Muslim Questions about the Trinity," The Thomist 74/1 (2010): 85-104.

24 Sandra Toenies Keating, "Refuting the Charge of Tahriif: Abū Rā’ița (d. ca. 835) and His 'First Risāla on the Holy Trinity'," in Ideas, Images, and Methods of Portrayal: Insights into Classical Arabic Literature and Islam, ed. Sebastian Günther (Leiden-Boston: Brill, 2005), $41-57$. 


\section{Conclusion}

The movement of reform put into motion by Muhammad in the early seventh century did not grow out of a simple desire to create a community of likeminded 'Believers', nor is it the remnant of confused and misunderstood Jewish or Christian teachings floating around the Arabian Peninsula. The Qur'ān and the earliest teachings of Muhammad display a clear theology of revelation that, though not systematically presented, is concerned with establishing the credibility of the nascent community. Over time, it comes to be articulated in a way that emphasizes its supersessionist character. It is not, however, a type of supersessionism that desires to suppress or destroy monotheistic religions already in existence. In fact, it depends on them. Rather, this is a forwardlooking supersessionism, intent on incorporating Muhammad and his followers into the greater plan of salvation history. To do this, the Qurān insists on God's justice, equality among all believers, and equitable access to revelation. Nevertheless, without a notion of tahriff, such a vision becomes nearly impossible to defend. 